\section{NATURE \\ No. 3870 SATURDAY, JAN. I, 1944 \\ Vol. 153}

\section{CONTENTS}

The Education Bill

Scientific Personnel in Industry

History of Elephants. By Prof. D. M.S. Watson, F.R.S.

The Training of a Regional Planner. By Prof. A. E. Trueman, F.R.S.

Dichroism. By Dr. W. D. Wright

U.S. National Patent Planning Commission. By Sir William Jarratt

Letters to the Editors :

\title{
THE EDUCATION BILL
}

T $\mathrm{N}$ several recent issues (NATuRE, 152, 393, 427, 455, $483,517,545$ ) we have dealt with the White Paper which heralded the Education Bill, beginning with a general survey, and proceeding to special aspects which in our judgment most nearly touch the real problems of education in Great Britain. We now have before us the long-awaited Education Bill, with the accompanying Explanatory Memorandum*. Let it be said at once that the Bill goes far to meet the criticism and the suggestions which we, like many others, have ventured to express.

First, however, comes an unanticipated change which happens to be of cardinal importance. At present there is no real Ministry of Education. The 9 functions of the President of the Board of Education 2 are vaguely defined as "the superintendence of

Tricotyledony. By H. E. Holtorp

Scientific Centenaries in 1944. By Eng.-Capt. Edgar C. Smith, O.B.E., R.N.

Obituaries :

Sir Edward Poulton, F.R.S. By Prof. G. D. Hale Carpenter, M.B.E.

Mr. H. F. Witherby, M.B.E. By N. B. Kinnear : News and Views.

Structure of Nucleic Acid in the Dividing Cell.Prof. J. Masson Gulland, G. R. Barker and D. O. Jordan

Aerial Disinfection.-J. E. Lovelock, $\dot{0}$. M. Lidwell and W. F. Raymond.

A Thermolabile Accessory Growth-factor to Rhizobium.-Dr. H. K. Chen and M. K. Hsü .

Localization of Vitamin $\mathrm{C}$ in Belascaris marginata. -G. R. Hill and J. D. Smyth .

Divergent-Beam X-Ray Photography,-Dr. Kathleen Lonsdale

Secondary Non-Lave Reflexions from Phloroglucine Dihydrate.-Prof. K. Banerjee and C. R. Bose

Abnormal Dissociation in Flame Gases.-Dr. A. S. Leah

A New Technique for the Ultimate Microanalysis of Organic Compounds.-R. Belcher and C. E. Spooner

Two New Carbonyls : Copper and Tellurium.Dr. P. L. Robinson and K. R. Stainthorpe

Ice-Crystal Haloes.-D. B. O. Savile.

Grey Mould (Botrytis cinerea) of Flax.-Dr. John Colhoun

Future of Anthropology.-The Writer of the Article

Mathematics as a Cultural Subject.-P. J. Wallis

Area Heating.-A. E. Margolis ; Dr. L. E. C. Hughes

Research Items

Feeding Waste Apples to Poultry. By H. Temperton : Cleansing of Milk Bottles. By Dr. G. Lapage

Palzontology without Fossils in the 'Bird-Wing'

Butterflies. By Dr. A. Steven Corbet

Studies of Population Changes

12

13

14

15

17

\section{Editorial and Publishing Offices \\ MACMILLAN \& CO., LTD.,}

ST. MARTIN'S STREET, LONDON, W.C.2.

Telephone Number: Whitehall 8831

Telegrams : Phusis Lesquare London

Advertisements should be addressed to

T. G. Scott \& Son, Ltd., Talbot House, 9 Arundel Street, London, W.C.2 Telephone : Temple Bar 1942

The annual subscription rate is $\$ 4100$, payable in advance, Inland or Abroad. All rights reserved. Registered as a Newspaper at the General Post Office matters relating to education in England and Wales", the result being that, however convinced the President may be that a certain step is desirable, he may have no power to act, but may only be able to offer advice and bestow his blessing. The Bill proposes a radical change. There is to be no change of name. We shall still have a Board of Education and a President (with rank of Minister), but the latter will be equipped with powers which mean that we shall have something akin to a Ministry of Education, just as surely as we have a Ministry of Works or of Labour. Any fear of over-centralization of power is allayed by the importance of the functions allotted to the local authorities. The addition of Central Advisory Councils for England and Wales respectively, charged with the duty of advising the Minister on "such matters of educational theory and practice as they think fit", is a signal that the Board is meant to be a great deal more than an administrative machine.

Broadly speaking, the White Paper was received with a chorus of approval, both in Parliament and in the country, at least with regard to its purely educational proposals. Perhaps the most widely expressed sense of disappointment related to the "exceeding lack of speed" implied in the Paper. The Bill meets this criticism by taking the bold step of fixing April 1, 1945, as the date for raising the schoolleaving age to fifteen, the President being empowered, however, for a period limited to two years, to retain the age of fourteen where it is impossible to provide the necessary buildings and teachers in time. The same date is fixed for the coming into operation of provisions regarding health and physical training, the modification of the dual system, religious education, and the adjustment of the present system of local administration. The date for raising the leaving age to sixteen is to be fixed by Order in Council, as soon as the Minister deems it practicable. So also will the date on which it will become the duty of local authorities to secure the provision of the necessary facilities for the compulsory part-time education of young persons.

Another of the rather bitter cries evoked by the

* A Bill to Reform the Law relating to Education in England and Wales. Pp. xii +98 . 18. $6 d$. net. Education Bill: Explanatory Memorandum by the President of the Board of Education. (Cmd. 6492.) Pp. 14. 3d. net. (London: H.M. Stationery Office, 1943.) 
White Paper is met by a financial allocation for technical and adult education more than three times as large as that proposed in the Paper.

The duty of local authorities to secure adequate provision of primary and secondary schools, and not merely, as at present, to keep efficient the elementary schools in their areas, is to include the duty of providing nursery schools. The provision of these schools was left as a power only by the Act of 1918, and, as the event has shown, the power has been little used, notwithstanding the acknowledged necessity for these schools from the point of view of social amelioration. In this respect, as in many others, the assent of Parliament will amount to an intimation to local authorities that the nation has made up its mind on the subject.

The other failure to carry out the intention of the Act of 1918 was that which related to the ill-fated day continuation schools, opposed by the less farseeing kind of employer, and scarcely welcomed by boys and girls, who had no desire to be sent to school again. The Bill provides for part-time continued education, not in day continuation schools, but in young people's colleges. The change of name, though perhaps sounding slightly pretentious, is exactly in the right direction, because it implies for the young person an entirely fresh start, an increased freedom from the restraints necessary during childhood, and a new opportunity of practising self-mastery. Attendance is to be obligatory for all young persons up to the age of eighteen who are not receiving full-time education. The arrangement of times is left to the local authority, but otherwise part-time education will be similarly organized throughout England and Wales.

An outstanding feature of the Bill, representing a considerable advance upon the White Paper, is that the way is opened for better provision for physically or mentally handicapped children. Hitherto the duty of ascertainment by the local authority has been restricted to defective and epileptic children. It is now extended to all types of children needing special educational treatment, including those who have come to be known as maladjusted. Also, the requirement that a handicapped child must be certified as defective before he can receive special treatment is removed. It will be the duty of the local authorities to provide special schools for the seriously handicapped, and special treatment for the less serious cases. From our point of view there are in this subject two points of compelling interest : first, that compassion towards those who are not to be winners in life's race is one of the fine things in a democracy, and, secondly, that the remedial treatment now possible is the result of applying scientific methods. In that connexion we may mention also the more general power which the Bill confers on a local education authority to "make such provision for conducting or assisting the conduct of research as appears to the authority to be desirable for the purpose of improving the educational facilities provided for their area". In this forward step one sees the promise of the substitution of scientific method for empiricism and guesswork. A similar blend of humanity and efficiency is seen in the powers conferred upon local authorities with regard to medical inspection and treatment, the provision of milk and meals, of boots and clothing-the parent to pay according to his means or lack thereof.

One result of current discussions about public schools has been to bring to the front the general question of boarding-schools for children of the unprivileged, when that arrangement seems desirable. In response to the arguments brought forward, the Bill provides that a local authority may set up a boarding school "for pupils whose education renders their residence away from home desirable, either because their parents desire that they should be educated as boarders or by reason of the remoteness of their homes or of other circumstanees". Here it may be mentioned that the Bill maintains a stony silence as to the public schools, notwithstanding the lively discussions which have occurred lately, and the numerous letters that have appeared in the correspondence columns of The Times and of other newspapers. It is scarcely to be expected that the same silence will be maintained during the passage of the Bill through Parliament.

As to the coming Parliamentary debate, it is devoutly to be hoped that those prophets are wrong who foresee that most of it will be taken up by lengthy and perhaps acrimonious tirades about the dual system of control and the cognate question of religious education. Let anyone examine the records of the debates on the Bill of 1870 , and let him cross out the parts relating to the denominational disputes, and he will find that there is not much left. We do not want, and we are sure that the general public does not want, a repetition of that vain war of words. Apart from 'the secular solution', of which we used to hear so much, but for which the general public is not prepared, there is only one way-the way of compromise, of give and take, which is essential in a democracy, and in which the British are said to excel. We trust that almost the last word has been said by way of patient and sincere and honestly sought compromise on these questions, it being known beforehand that as no one can get the whole of what he wants, so everyone will get some of what he wants. Thus the energies of Parliament would be available for educational matters which come nearer to the business and bosoms alike of parents and teachers and administrators.

One of those matters we account of vital importance is the development of a real democracy, in which every young citizen gets the opportunity to which he is entitled by his abilities. The White Paper proposed a division of secondary education into three types, to which there should correspond grammar schools, technical schools, and modern schools. The many virtues of the existing secondary schools, which inherited the traditions of the old grammar schools, were fully recognized, as also their gradual failure to meet the needs of able children who ought never to have been attracted into a type of school pre. dominantly academic in its outlook. For them it was proposed that the secondary technical school should be developed, taking its start from the existing 
junior technical schools and technical colleges. By many critics these proposals have been denounced, the grammar school as lopsidedly bookish, and the technical school as unlikely to engender that interest in the humanities which is one of the hall-marks of the well-educated man, and without which science cannot adequately express itself.

But the chief anxiety of some of the most experienced critics has been about the proposed modern schools, which must be the schools of the masses. It is perfectly true that the intention is to bring these schools up to the standard of the grammar schools in point of buildings, equipment, staff, size of classes, 'amenities', and so on. But just as the existing secondary schools inherited the traditions of the old grammar schools, so these senior or modern schools will inherit the traditions of the old elementary schools, into the details of which we need not enter. The staunch adherents of the democratic ideal must now, and for years to come, insist upon the fair promises embodied in the Bill being faithfully carried out, and they may have a hard struggle. The Bill does not lay down a three-fold division of the new secondary system, but leaves the local authorities to propose their plans of development. In other words, the Bill leaves room for experiment, even in the direction of the multilateral organization of American high schools. It is to be hoped that this ordered freedom to experiment will be benevolently regarded by the Minister, and will lead to valuable results. The general ends in view would be furthered if it could be arranged that a teacher's remuneration should depend upon his qualifications and experience, and not upon the kind of school in which he teaches. It would be a happy day for British education if some of the ablest and most enterprising members of the teaching profession could feel quite free to teach in any kind of school, without forfeiting one jot or tittle of their professional rights and privileges.

\section{SCIENTIFIC PERSONNEL IN INDUSTRY}

$\mathbf{N}^{\circ}$ one who has followed the recent discussions and reports on industrial and scientific research can have failed to notice the emphasis which has been placed on the research worker himself, and on the importance of ensuring that the conditions of service are such as to attract men of the highest ability and to retain their keenness and loyalty.

There is no more welcome passage in the report* of the Industrial Research Committee of the Federation of British Industries on "Industry and Research" than that which deals with the scientific worker in industry. It is clearly recognized that on the proper position of the research worker within the organization employing him depends to some extent the power of industry to attract the best scientific brains to its service. Nevertheless, the report finds it necessary to point out that the best results can only be obtained when the research staff is taken fully

* Federation of British Industries. Industry and Research : Report of the F.B.I. Industrial Research Committee. Pp. 24 . (London: Federation of British Industries.) into the confidence of the management and given a definite standing in the hierarchy of the organization. The research worker cannot be expected to perform his duties efficiently unless he has at his disposal all relevant information which is in the possession of the organization of which he is a member.

The report goes on to acknowledge that publication of the scientific aspects of his work is a legitimate ambition of every scientific worker, and that such ambitions are not as a rule inconsistent with the interests of firms engaged in competitive industry ; on the contrary, such publication increases the prestige of the firm concerned. Again, research and development can generally only be efficient on the basis of co-ordinated team-work, with a team properly balanced as between the leader and his various grades of assistants. The personality of the leader is of the greatest importance; a successful leader is one who appreciates the ambitions and capabilities of the separate members of his team and has the gift of communicating to them his own enthusiasm and a full appreciation of the objects the team is seeking to achieve; above all, he must be able to make discriminating acknowledgment of the contribution of each member of the team to the common objective. Sir Lawrence Bragg also has emphasized the need for more inspired leaders in industrial research, and suggested that we should divert more of the national genius to industrial research by recruiting potential leaders of this kind into industry, where they should be coached for positions of high responsibility. In his view the Central (Scientific and Technical) Register could be used to locate and recruit such men.

It may be encouraging to find such statements in the report of the Federation of British Industries, but neither here nor in the comments on the benefit that has flowed from the transfer of research workers having the requisite personal qualifications to commercial, administrative and other branches of activity is there the note of conviction that makes them something more than platitudes. The more an organization is staffed on all its sides by persons having an appreciation of science and research, the more progressive and adaptable to changing circumstances it is likely to be. Little benefit indeed will be derived from increasing the numbers of those engaged on research if trained minds are not more fully employed in other branches of industry, and the general scientific outlook of industry must be raised if the understanding and application of scientific inventions, discoveries and developments by industrial firms are to be increased.

We miss in the report the urgent sense of the primary importance of seeing that scientific workers of the highest quality are first attracted to industry and then set to work under conditions which give the utmost play and stimulus to their creative powers. That consciousness clearly inspired the motion tabled in November in the House of Commons by a large number of members of all parties, asking for wider State support in planning future developments for research, teaching and higher learning as a whole, including provision for a far greater number of persons highly trained in science and technology. Again, the 